\title{
Testing of selected probiotic properties of lactic acid bacteria isolated from vegetarians and meat-eaters faeces
}

\author{
Eva Hybenová, Lucia Birošová, Kristína Nagyová, Júlia Štofirová, \\ Nikoleta Šaková, Petra Olejníková, Barbora Kaliňáková \\ Department of Nutrition and Food Assessment, Faculty of Chemical and Food Technology, \\ Slovak University of Technology in Bratislava, \\ Radlinského 9, SK-812 37 Bratislava, Slovak Republic \\ eva.hybenova@stuba.sk,lucia.birosova@stuba.sk
}

\begin{abstract}
The aim of this work was to evaluate presence and properties of lactic acid bacteria in the faeces of 240 volunteers with various nutrition habits (vegetarians versus meat-eaters). Lactic acid bacteria counts in all age groups were nearly 5 or 6 logarithmic orders. Significantly higher amounts were found in women. Subsequently, based on the age and dietary pattern of probands, four samples were selected for isolation of lactic acid bacteria and identification of isolates in order to assign them to bacterial species. About 80 lactic acid bacteria were isolated from the faeces of young (21-30 years) and older (51-60 years) vegetarians and meateaters. The identification of the isolates was based on their morphological and biochemical characteristics. Isolates belong to lactobacilli, bifidobacteria, enterococci and propionibacteria. Surprisingly, bifidobacteria were predominated in older age group. The following probiotic properties were determined: survival at low $\mathrm{pH}$ value, and bile salt hydrolase activity. All strains were negative in bile salt hydrolase activity, but their growth was not inhibited in the presence of bile. The results from the study of survival at low $\mathrm{pH}$ value showed considerable variability in both dietary groups regardless the age of probands. However, it can be concluded, that bacteria isolated from the samples of older probands were more sensitive to acid $\mathrm{pH}$.
\end{abstract}

Keywords: gastrointestinal tract, lactic acid bacteria, meat-eaters, vegetarians

\section{Introduction}

The human gastrointestinal microflora represents an ecosystem of the highest complexity. In the gastrointestinal tract exists variability in bacterial numbers and populations. The human large intestine consists of 400-500 different cultivable species. The groups consist of different rods and cocci, such as bacteroides, bifidobacteria, lactobacilli, peptostreptococci, enterococci, coliforms, ruminococci, methanoges bacteria and acetogens. A number of different factors are able to affect the composition of the colonic microbiota, e.g. composition of the diet, aging, stress, health status, and environmental cicrcumstances (Aureli et al., 2011, Berg, 1996, Collins et al., 1998, Fooks et al., 1999, Guarner and Malagelada, 2003, Holzapfel and Schillinger, 2002).

Selected strains of the lactic acid bacteria (LAB) belonging mainly to the genera Lactobacillus and Bifidobacterium have been used many years in the food production, predominantly in the manufacture of fermented dairy products and have GRAS (Generally Recognized As Safe) status (Collins et al., 1998, Dunne et al., 2001, Del Piano et al., 2006). In the three recent decades lactobacilli and bifidobacteria are being used as probiotics. Probiotics according to the World Health Organization (WHO) are defined as "live microorganisms which, when administered in adequate amounts, confer a health benefit on the host" (Aureli et al., 2011, Seale and Millar, 2013). Criteria for the selection and assessment of probiotic lactic acid bacteria include: human origin, nonpathogenic behavior, resistance to technologic processes (i.e. viability and activity in food or dietary supplements), resistance to gastric acidity and bile toxicity, adhesion to gut epithelial tissue, production of antimicrobial substances, ability to modulate immune responses, and ability to influence metabolic activities (e.g. cholesterol assimilation, lactase activity, and vitamin production) (Collins et al., 1998, Dunne et al., 2001, Morelli, 2007, Gueimonde and Salminen, 2006, Mattila-Sandholm et al., 2002).

The first criterion for selection of probiotic bacteria, the human origin of the strain, is often discussed. This criterion is based on the observation, that bacterial species present in the intestinal microflora may have a better chance of survival in their native environment (Collins et al., 1998).

Numerous studies reported health-promoting properties of lactic acid bacteria in animals and humans. These properties include: enhancing the bioavailability of minerals (calcium, iron, manganese, copper and phosphorus), synthesis of several vitamins (B and $\mathrm{K}$ groups), prevention and 
treatments of gastrointestinal disorders (diarrhea, gastrointestinal and urogenital infections), treatments of hypercholesterolaemia, and lactose intolerance, reduction in pro-carcinogenic enzymes, stimulation of the immune system, and treatment of food-related allergies (Aureli et al., 2011, Collins et al., 1998, Dalié et al., 2010, Fooks et al., 1999, Guarner and Malagelada, 2003, Holzapfel and Schillinger, 2002, Seale and Millar, 2013, Nomoto, 2005, Prescott and Björkstén, 2007, Saad et al., 2013, Salminen et al., 1998, Shah, 2007, Sullivan and Nord, 2002). Recently research suggests, that probiotics may have also anti-obesity effects (Kovatcheva-Datchary and Arora, 2013).

The object of our work was isolation and identification of lactic acid bacteria from the faeces of meateaters and vegetarians and analyse the basic probiotic parameters of LAB isolates involving the survival at acid $\mathrm{pH}$-value and bile salt hydrolase activity.

\section{Material and methods}

Lactic acid bacteria were determined in the human faeces of probands involved in the project. The probands $(n=240)$ were divided according to the dietary patterns into groups of vegetarians $(n=136)$ and meat-eaters $(n=104)$. The group of vegetarians included vegans, lactoovovegetarians and semivegetarians. The probands were men and women at age from 21 to 60 years.

\section{Enumeration of lactic acid bacteria}

Lactic acid bacteria were determined in the faeces using dilution of samples in brain heart infusion and inoculation on Rogosa-agar plates (Biokar Diagnostics, France). The plates were incubated anaerobically at $37^{\circ} \mathrm{C}$ for $24-72$ hours. The bacterial colony forming unit (cfu) per gram of wet faeces was calculated and converted into a logarithmic equivalent.

\section{Isolation of $L A B$}

Four samples of faeces were choosen for isolation of lactic acid bacteria. Two samples were from the age group of 21-30 years old probands: one sample labelled as ZVI from 23-years old vegetarian women (18 isolated strains), and the sample labelled as ZNI (19 isolated strains) from 26-years meat-eater women. The other two samples were from the age group of 51-60 years old probands: 54-years old vegetarian women, sample labelled as ZVII (19 isolated strains), and 51-year old meat-eater man, sample labelled as MNI (20 isolated strains).

LAB were isolated from the human faeces by appropriate dilutions with saline, plated on MRS (MERCK, Germany) and Rogosa Bios agars (Biokar
Diagnostics, France) and incubated anaerobically at $37^{\circ} \mathrm{C}$ for $2-3$ days. Isolated colonies were picked up and transferred to MRS broth. They were propagated twice and streaked on MRS agar to check the purity of the isolates.

\section{Identification of isolates}

The LAB isolates were examined microscopically and morphological characteristics were noted. Key features for identification were Gram-staining, catalase test, growth at 15 and $45^{\circ} \mathrm{C}$, gas production from glucose in MRS broth using Durham tubes, and determination of the sugar fermentation spectrum using API 50 L Lactobacillus identification system (BioMérieux, France) and ANAEROtest 23 (Pliva-Lachema Diagnostika, Czech Republic). For all tests bacterial overnight cultures were prepared. The lactic acid bacterial overnight cultures were prepared in MRS broth at $37^{\circ} \mathrm{C}$ for $16-18 \mathrm{~h}$ (Betina et al., 1988, Kandler and Weiss, 1986).

\section{Survival of $L A B$ at low $p H$}

For survival of isolates at low $\mathrm{pH}$ value MRS broth was adjusted to $\mathrm{pH} 3.0$ with hydrochloric acid, sterilised, and the survival determined at $37^{\circ} \mathrm{C}$ for 3 hours. The inoculation number of LAB isolates was ca. $10^{6} \mathrm{cfu} / \mathrm{ml}$.

\section{Bile salt hydrolase activity assay}

Bile salt hydrolase activity was tested according to method of Daskevicz and Feighner. MRS agar plates supplemented with $0.5 \%(\mathrm{wt} / \mathrm{vol})$ of the sodium salt of taurodeoxycholic acid (TDCA) were prepared and inoculated with $10 \mu$ l overnight culture of LAB isolates. MRS agar plates without TDCA were used as control. The plates were incubated anaerobically at $37^{\circ} \mathrm{C}$ for $72 \mathrm{~h}$ (Dashkevicz and Feighner, 1989).

\section{Results and discussion}

\section{Enumeration, isolation and identification of LAB}

Total number of LAB of all 240 faeces samples is summarised in Table 1. Lactic acid bacteria counts in all age groups were nearly 5 or 6 logarithmic orders. Significantly higher amounts of LAB were found in women. Surprisingly, the highest number of LAB were found in women older age groups (41-50 or 51-60).

The isolated strains on the agar plates formed round, small or larger, white to creamy colonies with typical mild lactic acid aroma. All isolates were Gram-positive, catalase-negative, non-sporing rods, cocci or bifidobacteria, often arranged in star-like or "V" patterns, typically called "bifido" arrangements (Betina et al., 1988). 
The counts of lactic acid bacteria in four chosen faeces samples are summarised in Table 2. The results showed differences in the counts of LAB within the ages of probands, and their dietary patterns. Significantly higher amounts of LAB were demonstrated in meat-eaters. Based on the informations from the dietary questionnaires, meat-eaters consumed lactic acid fermented products such as yogurt and cheese more frequently and in higher amounts as vegetarians.

Tab. 1. Number of lactic acid bacteria in faecal microflora of vegetarians (V) and nonvegetarians (NV) in $\log \mathrm{cfu} / \mathrm{g}$.

\begin{tabular}{|c|c|c|}
\hline \multicolumn{3}{|c|}{ Age group 21-30 } \\
\hline & NV & $\mathbf{V}$ \\
\hline Total & $6.03 \pm 0.47$ & $5.47 \pm 0.34$ \\
\hline Men & $5.87 \pm 0.40$ & $5.39 \pm 0.20$ \\
\hline Women & $5.78 \pm 0.30$ & $5.51 \pm 0.10$ \\
\hline \multicolumn{3}{|c|}{ Age group 31-40 } \\
\hline & NV & $\mathbf{V}$ \\
\hline Total & $5.26 \pm 0.50$ & $5.28 \pm 0.40$ \\
\hline Men & $4.97 \pm 0.20$ & $6.03 \pm 0.50$ \\
\hline Women & $5.59 \pm 0.10$ & $4.83 \pm 0.47$ \\
\hline \multicolumn{3}{|c|}{ Age group 41-50 } \\
\hline & NV & $\mathbf{V}$ \\
\hline Total & $5.58 \pm 0.50$ & $5.81 \pm 0.31$ \\
\hline Men & $4.80 \pm 0.80$ & $5.40 \pm 1.20$ \\
\hline Women & $6.60 \pm 1.40$ & $6.60 \pm 1.70$ \\
\hline \multicolumn{3}{|c|}{ Age group 51-60 } \\
\hline & NV & $\mathbf{V}$ \\
\hline Total & $5.90 \pm 0.50$ & $5.29 \pm 0.54$ \\
\hline Men & $5.00 \pm 1.50$ & $5.10 \pm 1.40$ \\
\hline Women & $6.50 \pm 1.80$ & $5.40 \pm 2.12$ \\
\hline
\end{tabular}

Tab. 2. Total number of lactic acid bacteria in the samples ZVI, ZNI, ZVII and MNI.

\begin{tabular}{|c|c|}
\hline Sample of faeces & Lactic acid bacteria $(\log \mathbf{c f u} / \mathbf{g})$ \\
\hline ZVI & $4.53 \pm 0.12$ \\
\hline ZNI & $5.85 \pm 0.20$ \\
\hline ZVII & $0.95 \pm 0.20$ \\
\hline MNI & $4.30 \pm 0.32$ \\
\hline
\end{tabular}

Abbreviations: ZVI - sample from 23-years vegetarian women; ZNI - sample from 26-years nonvegetarian women; ZVII - sample from 54-years vegetarian women; MNI sample from 54-year nonvegetarian man

According to the morphological and biochemical tests and microscopic observation the isolates were included to the genera Lactobacillus, Bifidobacterium, Lactococcus, Propionibacterium and Enterococcus. The classification of isolated cocci to the genus Enterococcus was based on the typical dark pink colour of colonies with metallic sheen on Slanetz-Bartley agar (Betina et al., 1988).

Lactococci and enterococci predominated in the samples ZVI and ZNI, while almost exclusively lactobacilli and bifidobacteria in the samples ZVII and MNI (older group of volunteers) were identified. Classification of LAB isolates to the species was performed by API 50 L Lactobacillus identification system and ANAEROtest 23 (Tab. 3).

Tab. 3. Lactic acid bacteria identified in the samples ZVI, ZNI, ZVII and MNI.

\begin{tabular}{|c|c|}
\hline Identified of LAB & $\begin{array}{c}\text { Percentage } \\
\text { of occurence }\end{array}$ \\
\hline \multicolumn{2}{|l|}{ Sample ZVI } \\
\hline Lactobacillus paracasei ssp. paracasei & 13,3 \\
\hline Lactococcus lactis ssp. lactis & 86,7 \\
\hline \multicolumn{2}{|l|}{ Sample ZNI } \\
\hline Enterococcus sp. & 68,5 \\
\hline Lactobacillus plantarum & 10,5 \\
\hline Lactobacillus paracasei ssp. paracasei & 10,5 \\
\hline Lactococcus lactis ssp. lactis & 10,5 \\
\hline \multicolumn{2}{|l|}{ Sample ZVII } \\
\hline Bifidobacterium breve & 100 \\
\hline \multicolumn{2}{|l|}{ Sample MNI } \\
\hline Bifidobacterium breve & 30 \\
\hline Lactobacillus catenaforme & 60 \\
\hline Propionibacterium ovidum & 10 \\
\hline
\end{tabular}

Abbreviations: ZVI - sample from 23-years vegetarian women; ZNI - sample from 26-years nonvegetarian women; ZVII - sample from 54-years vegetarian women; MNI sample from 54-year nonvegetarian man

\section{Surviving of lactic acid bacteria at low pH}

The secretion of gastric acid constitutes the main human biological barrier against most ingested microorganisms. Health beneficial lactic acid bacteria must overcome this defense mechanism. Before reaching the large intestine, probiotic bacteria must survive transit throught the stomach (Dunne et al., 2001, Del Piano et al., 2006, Morelli, 2007, Gueimonde and Salminen, 2006, Vinderola and Reinheimer, 2003).

The survival of lactic acid bacteria at low $\mathrm{pH}$ value is very important characteristic for application of those cultures as probiotics. Tolerance to acid $\mathrm{pH}$ simulates the conditions in the stomach. The survival of the isolates was tested in MRS broth adjusted to $\mathrm{pH} 3.0$ at $37^{\circ} \mathrm{C}$ during 3 hours. The inoculating number of $\mathrm{LAB}$ was $\mathrm{ca} .10^{6} \mathrm{cfu} / \mathrm{ml}$ regard to recommendation that probiotic concentrations 
must be greater than or equal to $10^{6} \mathrm{cfu} / \mathrm{ml}$ in the small intestine and $10^{8} \mathrm{cfu} / \mathrm{g}$ in the colon (Aureli et al., 2011, Collins et al., 1998). Recent data, a dose of 5 billion $\mathrm{cfu}\left(5 \times 10^{9} \mathrm{cfu} /\right.$ day $)$ at least 5 days has been recommended for therapeutical use of probiotic bacteria in clinical practice (Iannitti and Palmieri, 2010).

The results showed considerable variability in both dietary groups regardless the age of probands (Fig. 1-4).

According to the results shown in Fig. 1, the isolates ZVI 1-ZVI 16 survived at pH 3.0 very well, except the isolates ZVI 1 and ZVI 16, their cells number decreased by 2 log orders. More sensitive to low $\mathrm{pH}$ value were the isolates ZNI 1-ZNI 19 (Fig. 2); in all tested isolates dropped the counts of LAB by 1 or $2 \log$ orders.

In older age group (Fig. 3 and 4) was the ability to survive at acid pH significantly lower. Approximately $50 \%$ of LAB isolates from the faeces of 54-years old vegetarian women (isolates ZVII 1-ZVII 19) and $20 \%$ isolates from the faeces of 51 -years old meat-eater man (MNI 1-MNI 20) survived in MRS broth at acid $\mathrm{pH}$ value during 3 hours. However, the surviving isolates showed low viability, they grown very slow and prepared overnight cultures did not reach the desired number of cells.

Nevertheless, strain viability and maintenance of desirable characteristics during product manufacture and storage is a necessity for probiotic strains. Ability to multiply rapidly is the important factor for technical application of probiotic strain (Collins et al., 1998, Gueimonde and Salminen, 2006, Mattila-Sandholm et al., 2002).

The obtained results suggest that most of these human isolates could successfully transit the human stomach and may be capable of reaching the colon. However, the bifidobacteria predominated in the group of older probands, proved less acid resistant than the lactobacilli and lactococci occured in the younger group. These results are in agreement with the data reported by Dunne and colleagues (Dunne et al., 2001).

\section{Bile salt hydrolase activity}

Bile salt hydrolase (BSH) activity is a commonly observed phenomenon. BSH active bacteria may have a competitive advantage over other bacteria

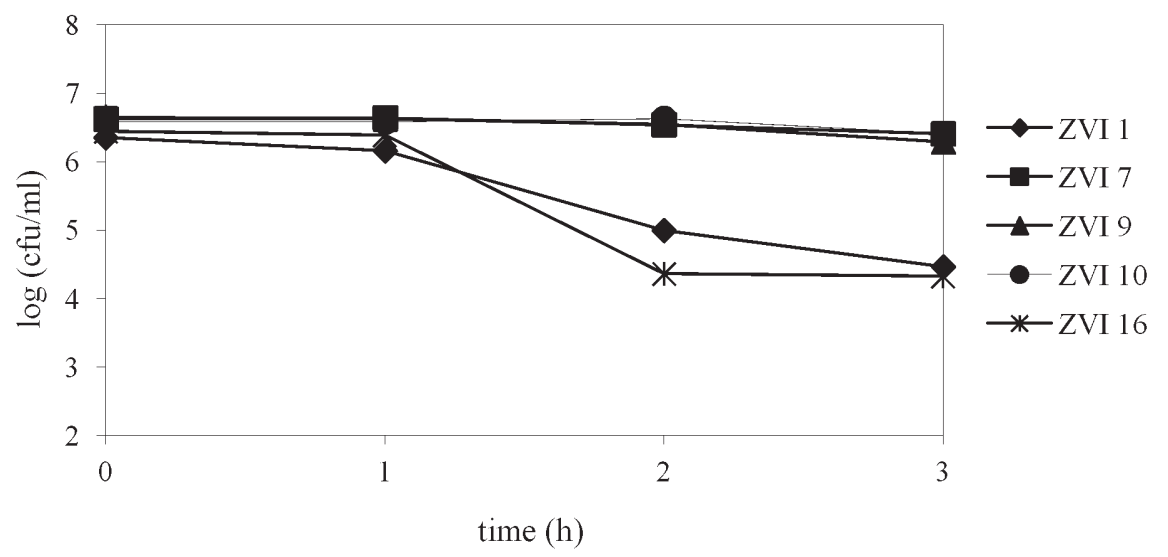

Fig. 1. Survival of the LAB isolates ZVI 1, ZVI 7, ZVI 9, ZVI 10, ZVI 16 in MRS-broth at pH 3.0 and $37^{\circ} \mathrm{C}(\mathrm{ZVI}$ - sample from 23-years vegetarian women).

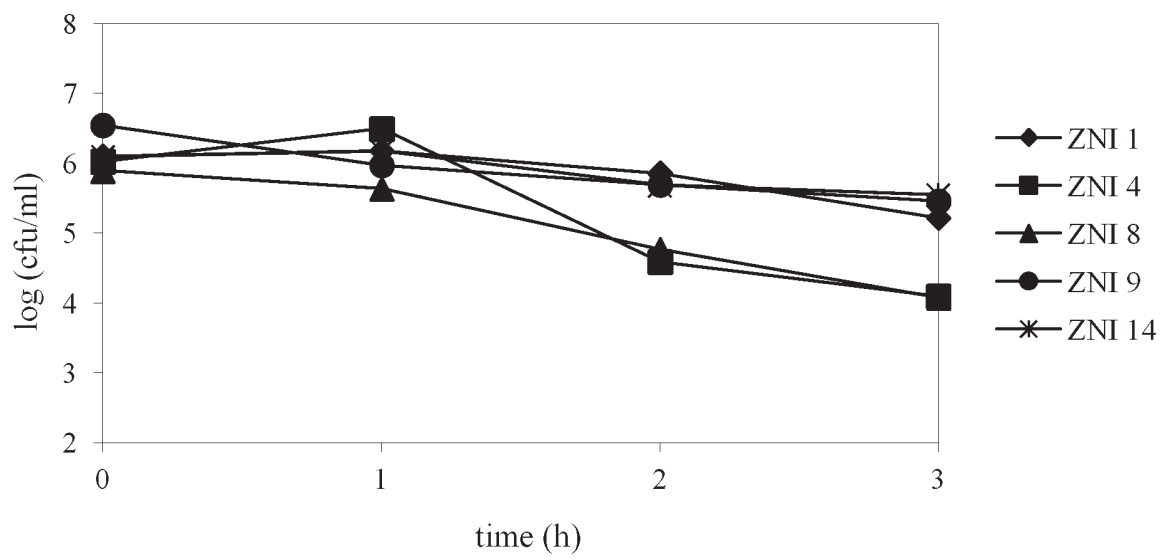

Fig. 2. Survival of the LAB isolates ZNI 1, ZNI 4, ZNI 8, ZNI 9, ZNI 14 in MRS-broth at pH 3.0 and $37^{\circ} \mathrm{C}$ (ZNI - sample from 26-years nonvegetarian women). 


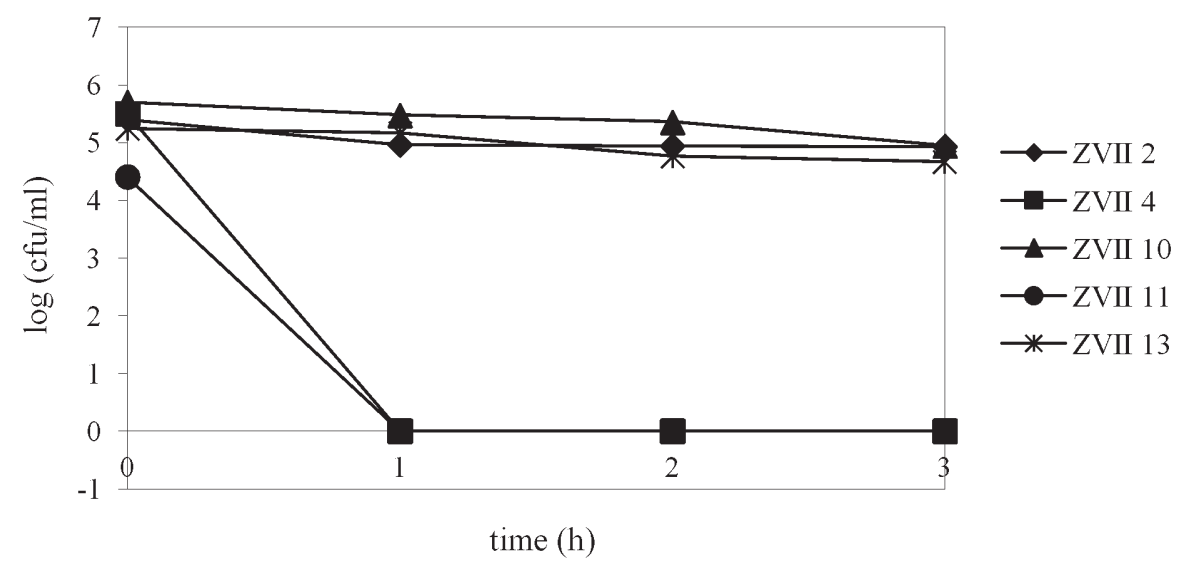

Fig. 3. Survival of the LAB isolates ZVII 2, ZVII 4, ZVII 10, ZVII 11, ZVII 13 in MRS-broth at pH 3.0 and $37^{\circ} \mathrm{C}$ (ZVII - sample from 54-years vegetarian women).

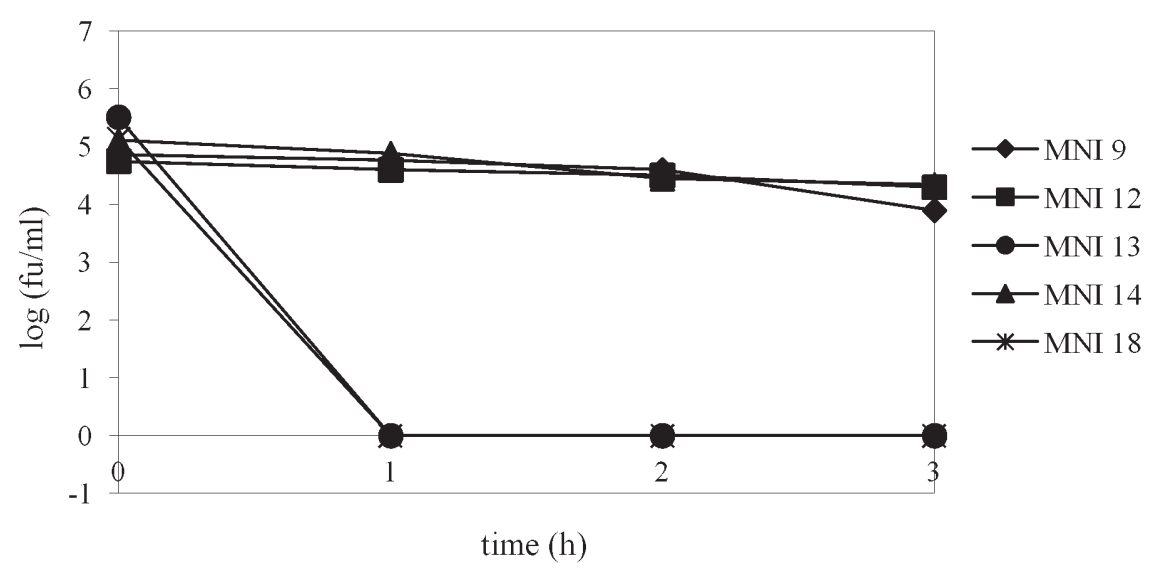

Fig. 4. Survival of the LAB isolates MNI 9, MNI 12, MNI 13, MNI 14, MNI 18 in MRS-broth at pH 3.0 and $37^{\circ} \mathrm{C}$ (MNI - sample from 54-year nonvegetarian man).

for surviving in the small intestine. The ability of strains to hydrolyze bile salts has often been included among the selection criteria for probiotic strain, and a number of bile salt hydrolases have been identified and characterized. However, recent data indicate, that microbial BSH activity could be potentially detrimental to the human host (Begley et al., 2006).

All LAB isolates were tested for BSH activity on MRS agar plates supplemented with $0.5 \%$ (wt/vol) TDCA. Bile salt hydrolase bacteria deconjugated taurine-conjugated bile salt producing deoxycholic acid. The deconjugation activity of bacteria can be manifested a) in copious amounts of deoxycholic acid precipitated around active colonies and diffused into the surrounding medium, b) bile salt hydrolase-active strains produces opague white colonies without precipitate halos. Bile salt hydrolase-inactive strains produced similar colony types on plates with or without TDCA. The results showed that hydrolysis of bile acid salts was negative in all studied strains, but the growth of strains in the presence of bile salt was not inhibited (Dashkevicz and Feighner, 1989).

\section{Conclusion}

The human gastrointestinal microflora represents an ecosystem of the highest complexity, which may be influenced by many factors including diet composition. In this work, human microbiota of slovak people with different nutrition habits with regard to representation of health beneficial lactic acid bacteria was investigated. These bacteria also called "probiotics" include predominantly strains belonging to the genera Lactobacillus and Bifidobacterium. The amounts of lactic acid bacteria decrease with age particularly in the 7th and 8th decades of life. Based on the results, lactic acid bacteria counts in all age groups were nearly 5 or 6 logarithmic orders. Significantly higher amounts were found in women and lower numbers of lactic acid bacteria in the dietary group of vegetarian were determined. Based on the informations from the dietary questionnaires, meateaters consumed lactic acid fermented products such as yogurt and cheese more frequently and in higher amounts than vegetarians.

Qualitative and quantitative representation of other microorganisms including total aerobes, total 
anaerobes, yeasts and filamentous fungi, Bacteroides spp., Clostridium spp., lecithinase-positive clostridia, Enterococcus spp., Listeria spp., Staphylococcus spp., Staphylococcus aureus, and Veillonella were examined and reported by Birošová et al. (2012).

The identification of LAB isolates from 4 samples of younger and older probands (man and women) shown, that they belong to the lactobacilli, bifidobacteria, enterococci and propionibacteria. The Lactococcus lactis ssp. lactis was prevalent in young vegetarian women, while enterococci predominated in the sample of meat-eaters young women. Only one species, Bifidobacterium breve, was identified in older vegetarian women. Lactobacillus catenaforme and Bifidobacterium breve were presented in meateaters man of older age.

The first criterion for selection of probiotic bacteria is human origin of the strain. This is based on the observation, that bacterial species present in the intestinal flora could have a better chance of survival in their native environment. Moreover, higher portion of strains of human origin were found to be tolerant to low $\mathrm{pH}$ and high bile in comparison to other strains.

The tolerance of LAB isolates to the acid $\mathrm{pH}$ value showed considerable variability in both dietary groups regardless the age of probands. However, it can be concluded, that more sensitive to acid $\mathrm{pH}$ value were bacteria isolated from the samples of older probands. Moreover, these isolates demonstrated lower viability. All LAB isolates were negative in bile salt hydrolase activity, but their growth in the presence of bile was not inhibited.

So far as is known, commercial probiotic bacteria have not been able to permanently colonize the human intestinal tract. Thus, regularly consumption of products with probiotics is highly desirable, especially after antibiotic treatment to prevent to growth of undesirable or pathogenic microorganisms. Lactic acid bacteria produce many compounds with inhibitory effects against a range bacteria. Safety application of lactobacilli and bifidobacteria in food products and food supplements is based on their GRAS (Generally Recognized As Safe) status due to their long history of safe use in foods.

\section{Acknowledgments}

This publication was created by realization of research project "Health effects of plant food and the possibility of reduction of health risks", supported by operating program "Research and Development financed from European fund for regional development" (ITMS code: 26240220022).

\section{References}

Aureli P, Capurso L, Castellazzi AM, Clerici M, Giovannini M, Morelli L, Poli A, Pregliasco F, Salvini
F, Zuccotii GV (2011) Pharmacological Research 63: 366-376.

Begley M, Hill C, Gahan CGM (2006) Applied and Environmental Microbiology 72: 1729-1738.

Berg RD (1996) Trends Microbiology 11: 430-435.

Betina V (1988) Mikrobiologické laboratórne metódy. 1. ed. Bratislava: ALFA.

Birošová L, Hudecová D, Kadrabová J, Kajaba I, Kaliňáková B, Kaliňák M, Kudláčková M, Lakatoš B, Mad’arič A, Mátéová R, Mišlanová C, Olejníková $\mathrm{P}$, Pauková V, Príbojová J, Šimečková O, Šimkovič M, Valachovičová M (2012) Výskum zdravotných efektov rastlinnej potravy a možnosti redukcie zdravotných rizík. 1. ed. Bratislava: Slovenská zdravotnícka univerzita.

Collins JK, Thornton G, Sullivan GO (1998) International Dairy Journal 8: 487-490.

Dalié DKD, Deschamps AM, Richard-Forger F (2010) Food Control 21: 370-380.

Dashkevicz MP, Feighner SD (1989) Applied and Environmental Microbiology 55: 11-16.

Del Piano M, Morelli L, Strozzi GP, Allesina S, Barba M, Deidda F, Lorenzini P, Ballaré M, Montino F, Orsello M, Sartori M, Garello E, Carmagnola S, Pagliarulo M, Capurso L (2006) Digestive and Liver Disease 38: S248-S255.

Dunne C, O'Mahony L, Murphy L, Thornton G, Morrisey D, O' Halloran S, Feeney M, Flynn S, Fitzgerald G, Daly C, Kiely B, O' Sullivan GC, Shanahan F, Collins JK (2001) American Journal of Clinical Nutrition 73: 386S-392S.

Fooks LJ, Fuller R, Gibson GR (1999) International Dairy Journal 9: 53-61.

Guarner F, Malagelada JR (2003) Lancet 8: 512-519.

Gueimonde M, Salminen S (2006) Digestive and Liver Disease 38: S242-S247.

Holzapfel WH, Schillinger U (2002) Food Research International 35: 109-116.

Iannitti T, Palmieri B (2010) Clinical Nutrition 29: $701-725$.

Kandler O, Weiss N (1986) Regular, Nonsporing GramPositive Rods. In: Bergey's Mannual of Systematic Bacteriology 2: 1208-1234.

Kovatcheva-Datchary P, Arora T (2013) Best Practice \& Research Clinical Gastroenterology 27: 59-72.

Mattila-Sandholm T, Myllärinen P, Crittenden R (2002) International Dairy Journal 12: 173-182.

Morelli L (2007) International Dairy Journal 17: $1278-1283$.

Nomoto K (2005) Journal of Bioscience and Bioengineering 100: 583-592.

Prescott SL, Björkstén B (2007) Journal of Allergy and Clinical Immunology 120: 255-262.

Saad N, Delattre C, Urdaci M, Schmitter JM, Bressollier P (2013) LWT-Food Science and Technology 50: 1-16.

Salminen S, Ouwehand AC, Isolauri E (1998) International Dairy Journal 8: 563-572.

Seale JV, Millar M (2013) Journal of Hospital Infection 84: $1-4$.

Shah NP (2007) International Dairy Journal 17: 1262-1277.

Sullivan A, Nord CE (2002) International Journal of Antimicrobial Agents 20: 313-319.

Vinderola CG, Reinheimer JA (2003) Food Research International 36: 895-904. 